\title{
Wewnątrz i na zewnątrz kultury. Komu potrzebna jest ,grzeczność"?
}

\section{Arkadiusz Jabłoński}

Uniwersytet im. Adama Mickiewicza w Poznaniu

yaboo@amu.edu.pl

\section{Streszczenie}

Badania pragmatyczne nad „grzecznościa” w istotny sposób ograniczaja możliwości opisu konkretnych sytuacji interakcji. Dzieje się tak głównie ze względu na to, że zdroworozsądkowe a zarazem normatywnie zorientowane pojęcie „grzeczności” uniemożliwia dostrzeżenie licznych zjawisk postrzeganych jako oczywiste przez rodzimych użytkowników kodu w rzeczywistych warunkach komunikacji. W artykule niniejszym dążono do ukazania przynajmniej kilku istotnych obszarów uzusu językowego, do opisu jakich studia „,grzecznościowe” nie sa w stanie dotrzeć. Postulowano rozszerzenie spektrum badań nad rzeczywistymi sytuacjami kontaktu językowego, poprzez odejście od wytacznie ,grzecznościowego” punktu widzenia, z wykorzystaniem ramy opisowej honoryfikatywności (modyfikacji honoryfikatywnej), jako zjawiska obecnego $w$ każdym rzeczywistym przekazie, powiazanego z osiagnięciem adekwatności komunikacyjnej komunikatu. Zwrócono również uwagę na fakt, że badania nad modyfikacja honoryfikatywna, obejmujace catość aktywności językowej jednostek i grup, moga (i powinny) dotyczyć także polityki językowej, pojmowanej jako wyposażenie użytkowników kodu choćby $w$ podstawowy zestaw wzorców jego użycia umożliwiajacych efektywna komunikacje

Stowa kluczowe: grzeczność, honoryfikatywność, adekwatność, procedura, protokót

\section{Abstract}

Inside and outside culture. Who needs "politeness"?

Pragmatic studies on „politeness” limit significantly the possibilities of description of actual situations of communication. It is mainly because of the fact that a common-sense oriented normative notion of ,politeness" makes it impossible to notice numerous phenomena taken for granted by the native users of a code in actual circumstances of communication. In this paper, it has been attempted to show at least some important areas of language usage that the „politeness" related approaches are unable to reach. It has been postulated to widen the range of studies over actual situations of communications, by abandoning the solely „politeness” focused point of view, with the implementation of the notion of honorific modification (HM), as a phenomenon present in any actual message, related to the achievement of communicational 
adequacy of a message. It has also been pointed out that the studies of HM, covering all communication related activity, may (and: should) be related also to the language policy, perceived as equipping the language users at least with basic set of its usage patterns, enabling effective communication.

Keywords: politeness, honorific modification (HM), adequacy, procedure, protocol

\section{Wstęp: Grzeczność" zdroworozsądkowa}

Badania nad modyfikacją kontekstową aktywności językowej, jak wskazywano wcześniej (Jabłoński 2007), nader często bazują lub wręcz: ograniczają się do zdroworozsądkowego pojęcia „grzeczności”. W fachowych i utylitarnych pracach nurtu pojawiają się wzmianki właściwie wyłącznie o pozytywnie wartościowanych aspektach działalności językowej.

Nieprzypadkowo autor najstarszego z przytaczanych tu opracowań wzmiankuje we wstępie do ogólnodostępnego w zamiarze opracowania o znamiennym tytule (Grzeczność ułatwia życie) ideę mówienia: „ładnie tzn. porządnie i dobrze [...]”, przywołując ład, porządek oraz właściwe zasady postępowania [...]" (Marianowicz 1962: 5). Inna praca (Goldnikowa 1973) także już w tytule (Obycie umila życie) zawiera pozytywnie wartościowane kompetencje społeczne. Szersze odniesienie do rzeczywistych wymogów komunikacji zdaje się motywować autorów wzmiankujących zbiór „form zachowania się, wyrażających zgodę na życie w społeczności” (Kamyczek 1974: 5) lub „kultury współżycia” (Pietkiewicz 1987: 7-33). Niekiedy pojęcie grzeczności wywodzone bywa od mówienia: „k rzeczy [...] stosownie do rangi rozmówcy, okazji i tematu rozmowy" (Jędrzejko, Kita 2002: 10). Tytuł źródła nowszego z kolei (Zgółkowie 2004) to Językowy savoir-vivre [...] w sytuacjach oficjalnych i towarzyskich, co pozwala być może wyłączyć z zakresu badań sytuacje „nieoficjalne”, a nawet i dopuszczać „nietowarzyskie” użycia kodu. Z kolei źródło dydaktyczno-słownikowe znaczenie hasła Etykieta językowa wyjaśnia poprzez: „grzecznościowe [...] normy obyczajowe” i „,atmosferę życzliwości, [...] szacunku (Płóciennik, Podlawska 2007: 66 -67). Mowa tu celowo o źródłach poradnikowych, które z ich definicji służą celowi innemu niż analiza pragmatyczna. Zarazem źródła te obrazują w sposób dobitny pewien spójny nurt przekonań na temat pojęcia „grzeczności” które należy wziąć pod uwagę w badaniach nad rzeczywistym wykorzystaniem kodu językowego. W źródłach obcojęzycznych (por Eelen 2001: 30-32) można odnaleźć echa rozróżnienia między zdroworozsądkową koncepcją „grzeczności” oraz jej definicją spełniającą kryteria naukowe. Źródła rodzime nader często zdają się tej dychotomii nie brać pod uwagę.

„Grzeczność” jako wydzielony obszar badań językoznawczych zdaje się skłaniać do metaforycznego opisu konkretnych aspektów zastosowania pojęcia podstawowego. Tak 
zapewne należy rozumieć pojmowanie „grzecznościowej gry” jako: „[...] mówienie partnerowi różnych rzeczy [...] które w intencji mówiącego są dla partnera miłe (ogólniej: dobre). [...] bezustanne [...] potwierdzanie, że partner jest [...] osobą ważną" (Marcjanik 1997: 5). Odniesienie do „Ważności” partnera komunikacyjnego pozostaje jednoznacznie pozytywne. W późniejszym opracowaniu ta sama autorka definiuje pojęcie grzeczności jako: „zachowania językowe i/lub niejęzykowe, których w danej sytuacji mówienia zaniechać nie wypada" (Marcjanik 2007: 8), podając zorientowaną procesualnie definicję: „Grzeczność językowa [...] zbiór [...] form językowych zachowań, przyporządkowanych określonym sytuacjom pozajęzykowym” (Marcjanik 2009: 1), jednak nie wpływa to na metodologię i konkluzje badawcze. Także źródło słownikowe definiowane jako: „pierwszy [...] słownik gromadzący wyrazy i wyrażenia o funkcji grzecznościowej” (Marcjanik 2014: 5) na pierwszy plan wysuwa raczej katalogowanie ilościowe postrzeganych jako pełniące funkcje „,grzeczne” jednostek niż odniesienie do konkretnych (i: kontekstowo zmiennych) wymogów komunikacji.

Metafora umowy społecznej wspiera przytaczaną przez Kazimierza Ożoga definicję: „umowa grzecznościowa o [...] nachyleniu pragmatycznym” (Ożóg 2005: 9). Dalej w tym samym tekście występują jednak pojęcia warunkowane normatywnie: „godność, osobowe traktowanie [...], życzliwość, skromność, wdzięczność [...], współodczuwanie”

\section{Rola i cele ,grzeczności” normatywnej}

Ujęciom normatywnym „grzeczności” nie brak zalet. Do takowych zaliczyć wypada:

1. Wygodę stosowania etykietek, przy jednoznacznie pozytywnym markowaniu pożądanych, akceptowanych (nawet jedynie: życzeniowo) społecznych wzorców zachowań.

2. Nośność edukacyjną, niezależnie od przyczyn, kontekstu i funkcji „grzeczności”.

3. Efekt zwrotny w postaci piętnowania zachowań postrzeganych jako niepożądane.

Zarazem ujęcia „grzeczności” usuwają z pola badań, istotny w rzeczywistych warunkach komunikacji, a pomijany w opisie „grzeczności”, warunek kompetencji operacyjnej uczestnika interakcji, pozwalającej na adekwatne osadzenie przekazu w środowisku komunikacyjnym (Yngve 1975). Ze względu na niejawność rutynowego tła zachowań (por. Garfinkel 2007: 5198), niemożliwe staje się odniesienie pojęć normatywnych do oczywistych w realiach danej kultury, z zewnątrz niewidocznych elementów interakcji. Praktycznie niedostrzegane pozostają 
wreszcie realia gier destrukcyjnych (Berne 1999) zachodzących w tle przekazu. Podejście normatywne pomija zatem co najmniej trzy aspekty rzeczywistej interakcji:

1. NIE ZAWSZE: „grzeczne” = ewidentne.

2. NIE ZAWSZE: ukryte = „,niegrzeczne” lub „nieistotne”.

3. NIE ZAWSZE: „grzeczność” = honoryfikatywność.

\section{Honoryfikatywność}

Honoryfikatywność (ang. honorific modification: HM to „modyfikacja wypowiedzi [...], wynikająca $\mathrm{z}$ [...] obligatoryjnego $\mathrm{w}$ każdej sytuacji [..] dążenia [...] do poprawności komunikacyjnej [...]” (Jabłoński 2012: 79). Definicja ta nawiązuje do obecnej w polskiej literaturze, acz, jak się wydaje, rzadko wykorzystywanej w praktyce opisu pragmatycznego, koncepcji wyróżnienia rang towarzyskich i komunikacyjnych (Huszcza 1996: 51-52). W jej praktycznym zastosowaniu do analizy środków językowego wyrazu odnosi się ona do warstw protokołu (środków językowych) oraz procedury (realizacji wzorców komunikacyjnych, por. Austin 1962: 14). Mowa tu, w szerokim sensie, o rozróżnieniu między postacią a wzorcami mowy (Hymes 1974: 51).

Kompetencja protokolarna i proceduralna wyznacza reguły języka i świata, w jakim przebiega komunikacja, z jej konkretnym wynikiem (Yngve ibid.) Honoryfikatywność wpływa na uzus (i: styl) komunikacji, warunkując sprawność komunikacyjną użytkowników języka. Polega na zarządzaniu ,informacją ukierunkowaną społecznie” (Levinson 1983: 89), co przekłada się na znamienne stwierdzenie faktu, że: „informacje o danej jednostce ułatwiają zdefiniowanie sytuacji” (Goffman 2000: 31), także poprzez „syntaktyczne związki między działaniami różnych, przebywających w swoim towarzystwie osób” (Goffman 2006: 3).

Cytowane w niniejszym tekście źródła pragmatyczne wykazują niezmiennie rozpoznanie opozycji językowych na stosunkowo wysokim poziomie abstrakcji, czego często próżno oczekiwać od prac najnowszych. Również wśród prac starszych wymienić można ujęcia nacechowane teoretyczną beztroską, z których przede wszystkim znaną pracę Brown i Lewinsona, opartą na nieudokumentowanym pojęciu „twarzy”, zaczerpniętym bezrefleksyjnie od Goffmana - i stąd w wywodzie niniejszym pomijaną - trudno uznać za użyteczną w perspektywie rzeczywistych badań nad osadzonym w kontekście przekazem. 


\section{Pułapki ,grzecznej normatywności”}

Ujęcie normatywne pozostaje ograniczone do opisu złożonej rzeczywistości językowej w markowaniu opozycji ilościowych, nie: jakościowych. W znaczniejszym stopniu liczy się rozpoznanie obecności lub nieobecności nacechowania grzecznościowego w przekazie niż powody i cele tak ukierunkowanych zabiegów językowych. Dla użytkownika języka w rodzimym, dobrze znanym środowisku komunikacyjnym, zastosowanie praktyczne mają właściwie jedynie opozycje:

grzeczny $\leftrightarrow$ niegrzeczny

grzeczny $\leftrightarrow$ grzeczniejszy

Nieścisłości normatywnego ujęcia „grzeczności” sprowadzić można do trzech obszarów:

I. Grzeczność sytuacyjna - dotyczy „grzecznej” części, nie zaś całości zachowań.

II. Grzeczność statyczna - w opozycji do „niegrzeczności” zachowań pozostałych.

III. Grzeczność semantyczna - ilość wykładników „grzeczności” przedkładana jest nad komunikatywność, która nie wynika z sumy składników przekazu (Jabłoński 2012: 52-65).

\section{Paradoks MMMP}

Nieco frywolny model MMMP (Machine for Making Messages Polite 'maszyny do ugrzeczniania wypowiedzi') dotyczy celowo paradoksalnego, automatycznego, bezkontekstowego „ugrzeczniania” przekazu. Cykl pracy urządzenia (MMMP Engine) opiera się na następującym algorytmie przetwarzania informacji:

START: WEJŚCIE (wiadomość źródłowa) $\rightarrow$

PRACA (czarna skrzynka: „,ugrzecznienie” wypowiedzi dostępnymi środkami) $\rightarrow$

WYJŚCIE (postać docelowa wiadomości - grzeczniejsza): KONIEC. (Jabłoński 2007a)

Zastosowanie algorytmu nie pozwala wykazać, czemu służyć ma pozakontekstowe „ugrzecznianie” wypowiedzi. Kompetencje wykorzystania środków „grzecznościowych” nie przekładają się automatycznie na lepsze ,wykonanie” zadania efektywnego komunikowania 
(aktywności społecznej, z określonymi przyczynami, celami i skutkami). Warto zwrócić uwagę na fakt, że niezależnie od doboru skali „ugrzecznienia” wypowiedzi źródłowych i docelowych, przedmiot badań w postaci konkretnego przekazu i jego umiejscowienia kontekstowego pozostaje dla badacza niedostępny. Pozorna ścisłość algorytmu MMP nie przekłada się na wyjaśnienie dopuszczalnych okoliczności i celów jego wykorzystania. Podobny, celowo absurdalnie skonstruowany przykład zastosowania definicji pocałunku (kissing) jako „,aktu bilabialnego, ingresywnego i pulmonarnego", w zupełnym oderwaniu od jego społecznych i komunikacyjnych uwarunkowań przedstawia Geis (1995: 14-15).

Ujęcie szerokie, bazujące na honoryfikatywności, ujawnia bogaty zestaw środków (niekoniecznie: „grzecznych”) modyfikacji przekazu, stanowiących wyraz społecznej „dojrzałości w języku” uczestników interakcji zdolnych realizować sytuacje społeczne.

Zastosowanie wyłącznie ujęcia wąskiego faktów językowych rodzi znaczne niespójności między metajęzykiem opisu a rzeczywistymi zjawiskami. Niżej skupiono się na trzech, z konieczności traktowanych w sposób uproszczony i schematyczny, zakresach niespójności, jakie można odnieść do wąskiego, zorientowanego właściwie wyłącznie „grzecznościowo” opisu zjawisk honoryfikatywnych w polskich źródłach:

1. Opozycja V/T i jej ,pokonywanie”.

2. Neutralność HM.

3. Wariacje norm: na przykładzie procedury przeprosin.

\subsection{Opozycja V/T}

Jedna z klasycznie rozpoznawanych opozycji pragmatycznych dotyczy doboru postaci zaimka typu T (w polskim: ty) lub V (w polskim: pan/pani/państwo) (Brown, Gilman 1960). Charakterystyczne że, jak zaznaczają sami autorzy, a co nader często bywa pomijane w próbach zastosowania opozycji T/V w analizie przekazu językowego, nie wszystkie rzeczywiste opozycje parametrów komunikacyjnych przekładają się w tak samo automatyczny sposób na dobór konkretnych postaci zaimkowych w przekazie językowym.

Warto przede wszystkim zbadać, z jakiego poziomu, w jaki sposób i w jakich warunkach rzeczywiście następuje akt „przejścia na T”. Niezależnie od tego czy, przytaczana chyba raczej celem dokumentacji archiwalnej, procedura bruderszaftu (Marcjanik 2009: 37) jeszcze istnieje, ujęcia normatywne zdają się nie dostrzegać częstej we współczesnym uzusie polszczyzny sytuacji wymuszenia T, gdy „przejście na T” nie jest konieczne ani nawet możliwe. Rodzi to 
potrzebę rewizji definicji: „Bycie na ty [...] jest rodzajem [...] zgody na wkraczanie w obszar prywatności” (Marcjanik 2009: 36), wymuszając refleksję na temat rzeczywistego dystansu i konsekwencji jego nominalnego „skrócenia”.

Opozycja T/V nie wyjaśnia wielu relacji, jakie bywają definiowane jako „pośrednie” (Marcjanik: 38-40), przy rzeczywistym braku rozróżnienia lub pomieszania obu rodzajów modyfikacji. Koncepcja „prywatności” rozciąga się zaś także na sytuacje proceduralne niepowiązane bezpośrednio z modyfikacją postaci zaimka. Oto wypowiedź typu: Pięknym kobietom nigdy nie odmawiam, przytaczana jako „komplement” (ibid. 2009: 9), o ile może w ogóle funkcjonować we współczesnej polszczyźnie (poza użyciem żartobliwym, bez związku z „komplementem”), nie wykazuje nacechowania $\mathrm{T}$ ani $\mathrm{V}$, podlegając zgoła innymi czynnikom niż „prywatność”, co można (z nieuniknionymi skutkami dotykalnymi) zweryfikować w rzeczywistej komunikacji.

Pośredni przynajmniej dowód na to, że ujęcia normatywne nie są powiązane z aktywnością komunikacyjną użytkowników polszczyzny to powszechny brak rozpoznania pewnych powtarzalnych wzorców komunikacji. Niepewność ról i niekonsekwencja w ich doborze: lęk przed rangą $\mathrm{V}$, dążenie ku $\mathrm{T}$, odzwierciedlane są w karykaturalnych decyzjach protokolarnych (Jabłoński 2013: 234-239).

Trudno oto uznać za przypadek fakt, że postaci Witam i Dzień dobry oraz Proszę Pana zostały w audycji w publicznej stacji radiowej wymienione jako rzekomo „neutralne” nagłówki wiadomości e-mail (RDC „Wieczór RDC” 2016.03.03). Obok wątpliwości, czemu takowa „neutralność” miałaby służyć, razi tu właściwie zupełny brak postaci poziomu V (Szanowny/i Panie/Pani/Państwo), które uczestnikom audycji nie wydały się „neutralne”.

W powszechnym użyciu wobec nauczycieli, przynajmniej w szkolnictwie podstawowym, stosowane są obecnie zwroty o zaszeregowaniu mieszanym (T/V) z użyciem imienia referenta, typu Pani Ania (zasłysz.), co ćwierć wieku temu byłoby nie do pomyślenia. Trudno wskazać pozytywne skutki pozajęzykowe takiej praktyki.

Popularność podobnej formy: Panie Arkadiuszu... (zasłysz.) ujawnia się także w stosunku do partnera proceduralnego o roli „klienta” - na przykład: ze strony konsultanta telefonicznego. O ile klient może nie godzić się na tak karykaturalny sposób tytułowania, zdecydowanie trudniejsze okaże się to $\mathrm{w}$ kontakcie $\mathrm{z}$ funkcjonariuszem państwowym (policjantem, urzędnikiem) używającym takiej formy. Zamierzchła postać urzędowego wołacza obywatelu nie została rozpoznana jako współcześnie przydatna, zaś postać wyszukana typu V (pan, pani) pozostaje, z niewiadomych względów, rozpoznawana jako nieodpowiednia w okolicznościach 
nominalnie oficjalnych. W postrzeganym jako mniej oficjalny kontakcie elektronicznym następuje z kolei wyraźny przechył ku T (por. Witaj Arkadiusz!), z użyciem imienia referenta, wykorzystywanym do niedawna wyłącznie w kontaktach intymnych.

\subsection{Neutralność HM}

Ujęcia normatywne cechuje brak rozpoznania modyfikacji zerowej, zgodny z binarnym paradygmatem logiki wyłączonego środka. Rozpoznaje się ,zasadniczo relacje dwojakiego rodzaju: na ty oraz na pan” (Marcjanik 2009: 33).

„Grzeczność” wymaga ponadto nacechowanej „sytuacji grzecznościowej”. Trudno orzec, czy na przykład zachowanie milczenia (gdy uczestnikowi interakcji nie przysługuje prawo do wypowiadania się lub gdy mówi ktoś inny) mieści się w tej definicji.

Brak nacechowania sytuacji można identyfikować z brakiem wymogów „grzecznościowych”, jednak nie z brakiem decyzji honoryfikatywnych. Można to wykazać poprzez koncepcje „,3. osoby honoryfikatywnej" - niezbędnego składnika opozycji honoryfikatywnych odnoszącego się do technik modyfikacji zerowej (Jabłoński 2013a). Niezręczności (honoryfikatywne: nie „grzecznościowe”) (Jabłoński 2015), we współczesnym uzusie polszczyzny bynajmniej nie wydają się wcale rzadkie:

- nadużycie rozkaźnika, por.: „Fundacja Viva po tym, jak okazało się, że na terenie Poznania wystąpi cyrk Korona zapowiedziała protest. Odbył się dzisiaj. Sprawdźcie, jak przebiegał" (PoznańNM 2016);

- nieuprawnione użycie postaci 2. os. czasownika: „Dlaczego nosisz obrączkę na palcu serdecznym?" (Popularnie 2016), co trudno uznać jedynie za wzmiankowane niekiedy „rozchwianie” rang komunikacyjnych (Marcjanik 2009: 168-170);

- wymuszona zupełnie zbędną modyfikacją czasownika w 2. os., męskoosobowość, por.: „Wybrałeś sposób zapłaty i dostawy zakupionych przedmiotów” (Allegro 2016);

- karykaturalne postaci (najprawdopodobniej: anglojęzycznych) kalek markowania wymuszonej przynależności: „Kącik dziecięcy to miejsce w telefonie, w którym Twoje dziecko może korzystać z aplikacji, gier, muzyki i filmów” (Windows Phone 2014).

Zjawisk tych nie sposób ująć w terminach normatywnych. Charakterystyczny pozostaje ich brak w spektrum odniesienia współczesnych opisów „,grzecznościowych”. 


\title{
5.3. Wariacje norm - przeprosiny
}

Kolejne zjawisko pomijane przez ujęcia normatywne „grzeczności” dotyczy wariacji norm „grzecznościowych”. Przedstawione ono zostanie na przykładzie opisu realizacji przeprosin w polskim środowisku komunikacyjnym. Oto zestaw odpowiednich haseł (ok. 100 wariantów!), przytaczany w specjalistycznym słowniku:

\begin{abstract}
sory, sorki, sorry, amsory, siorki, soława, sor, sor@, sor8, sora, soraja, soraki resoraki, soras, sorasek, sorasik, sorasiński, soraski, soraszki, soraś, sorawa, sorawczor, soraweczka, sorawiński, sorawka, sorawson, sorawuś, soraya, sorcia, sorciak, sorciarz, sorcie, sorciosław, sorczask, soreczka, soreczki, sorek, soreks, sorencja, sorencja babencja, sorencjusz, sorens, sorensen, sorensis, soreńka, soresunie, soret, sorewicz, sorex, soriks, sorimex, sorinki, soriso, sorka, sorka amorka, sorka majorka, sorkens, sorkes, sorki orki, sorki resorki, sorki sorki, sorki worki, sorkisorki, sorks, sorksy, sorkusy, sorniaczek, sorość, sorowinki, sorówa, soróweczka, soróweczki, sorówka, sorq, sorqa, sorra, sorrento, sorrymen/sorymen, sorson, sort, sorunia, sorunie, sorusieńka, sorwa, sorx, sory Batory, sory Gregory, sory memory, sory resory, sory wery, sory Winnetou, soryks, sri, sry, syry, wery sory, wielkie sorki, wielkie sorry/sory (Marcjanik 2014: 233-258).
\end{abstract}

Charakterystyczne, że w źródle oraz w innych opisach przeprosin autorstwa tej samej badaczki trudno napotkać odstępstwa od definicji przeprosin jako wdrażanych tak, „by rozmówca nie czuł [...] nic złego" (Marcjanik 2007: 219; 2009: 59). Znamienne są uwagi, że przepraszanie: „nie należy do rzeczy miłych [...] zwłaszcza mężczyźni unikają wszelkich strategii przepraszających [...] szukamy takich sposobów usatysfakcjonowania rozmówcy, żeby go zadowolić, a samemu nie stracić (ibid.), por. Sama nie wiem, jak to się stało. (ibid.), jak i wymóg „,zgodności wyrazu twarzy (miny) mówiącego z treścią wypowiedzi” (ibid.: 63).

Ostatni wymóg trudno jednak uznać za narzucony (jednostronny). Jest on przecież raczej także: narzucany i potencjalnie: inwazyjnie dwustronny. Umiejętnie wdrożone przeprosiny obligują nie tylko przepraszającego, ale także, a może przede wszystkim, przepraszanego. W polskim uzusie występuje znacznie większe zróżnicowanie w realizacji tej procedury niż opozycja miedzy przeprosinami „właściwymi” (,miłymi”?) a pozostałymi.

Brak przeprosin to niekoniecznie „łamanie norm” (Marcjanik 2009: 165-175). Można odwołać się w opisie tej procedury do pojęcia „projekcji własnej definicji sytuacji” (Goffman 2000: 38), co umożliwia nie tylko opis licznych niuansów dotyczących przeprosin, ale także rozpoznanie kreatywnych nadużyć proceduralnych.

Wariacje przeprosin nie są „niemiłe” i nie zależą od płci. Realizowane są według kryteriów proceduralnych (kontekst, status partnera itd.), w celu „ocalenia” sytuacji komunikacyjnej. Taki charakter wykazują również „fałszywe” przeprosiny w odmowach (z narzuceniem partnerowi 
sytuacji, w której nie może on protestować), por.: Przepraszam, ale nie mogę. Zaprzecza to stwierdzeniu, że: „Polacy nie umieją [...] odmawiać” (Marcjanik 2009: 7). Co więcej, są w stanie odmowę lub niezręczność tuszować deklaracją typu: Przecież przeprosiłem!

Manipulacje proceduralne mogą ewoluować ku grom komunikacyjnym, które dla strony inicjującej są „zawsze wygrane”. Wypowiedź: Sama nie wiem, jak to się stało daje się przecież wyjaśnić w terminach tzw. transakcji skrzyżowanych (Berne 1999: 21 i nast.). Destrukcyjna i manipulacyjna w istocie gra typu: „Ja to zawsze coś zepsuję.” realizowana jest przez uczestnika przyjmującego celowo rolę bezradnego Dziecka, wobec którego oczekiwana (w projektowanej sytuacji: jedynie możliwa) reakcja może przyjąć postać typu: Jaki/a on/a biedny/a, wymuszając manipulacyjnie na odbiorcy rolę wyrozumiałego Dorosłego, miast wymagającego Rodzica, surowo konstatującego: Co za niezdara!

\section{Zamiast wniosków}

Komunikacja stanowi część (przemyślanej, regularnej, rytualizowanej, długofalowej) aktywności społecznej. Pojęcie „grzeczności” odnosi się co najwyżej do aktu (jednostkowego, illokucyjnego bądź tylko lokucyjnego) „mówienia”. Honoryfikatywność dotyczy wypowiedzi językowej ze względu na jej właściwości perlokucyjne (= przyczyny/cele +kontekst + realizacja +skutki). Zależność stylu i celu komunikacji pozostaje bezsprzeczna.

Postulat formułowany w konkluzji niniejszego artykułu dotyczy rozwiązania istotniejszego niż się wydaje dylematu teoretyczno-terminologicznego. Odnosi się on do efektywnego (w tym: nastawionego na wyjaśnianie kultury „,z zewnątrz”, bez założenia zrozumiałości czegokolwiek z góry) orzekania o faktach językowych i komunikacyjnych.

Należy ponadto zaproponować (niezależnie zgoła od perlokucyjnych skutków wysunięcia takiego postulatu) rozważenie środków odpowiednio ukierunkowanej polityki językowej, celem zapewnienia dostępności wzorców efektywnej komunikacji. Wszystko to nie ze względu na postrzegane in abstracto „odgrzecznienie” współczesnej polskiej komunikacji językowej. To raczej brak rodzimych kompetencji honoryfikatywnych nader często jakże intensywnie doskwiera uczestnikom komunikacji nieefektywnej i karykaturalnej, a prowadzonej przecież nominalnie w języku polskim.

Co ciekawe, niedostatek kompetencji honoryfikatywnych, co autor z konieczności konstatować może co najwyżej w manierze indywidualnego wrażenia, rzadko raczej dotyczy nieumiejętności rozpoznania zabiegów słowotwórczych (sory Batory, sory Gregory, sory memory, sory resory, sory wery, sory Winnetou). Nie są natomiast zjawiskiem odosobnionym 
wyrażane otwartym tekstem prośby o „przejście na ty”, motywowane poczuciem niezręczności z powodu nieumiejętności wykorzystania przez użytkownika języka polskiego postaci pan/pani/państwo. Również rodzimi funkcjonariusze państwowi doświadczają wyraźnych problemów w rzeczywistym użyciu takich postaci. Podobny brak kompetencji językowych można zaobserwować w cytowanych wyżej przykładach nieumiejętności zastosowania „3. osoby honoryfikatywnej”. Odwołanie do polityki językowej czynione w tym miejscu należy traktować jako zdecydowanie odległe od normatywnego narzucania określonych wzorców komunikacji. W odniesieniu do zarysowanych ogólnie wyżej zjawisk można bowiem stwierdzić, że użytkownik polszczyzny nader często nie dysponuje współcześnie adekwatnym zestawem wzorców wykorzystania opozycji honoryfikatywnych. Kształt współczesnych źródeł fachowych dotyczących pojęcia „grzeczności”, nader często oderwanego od jego kontekstowych przyczyn i skutków, zdaje się fakt ten potwierdzać.

\section{Bibliografia}

Austin, John Langshaw (1962) How to Do Things with Words. Oxford: Oxford University Press.

Berne, Eric ([1964] 1999). W co graja ludzie. Psychologia stosunków międzyludzkich [Games People Play. The Psychology of Human Relationships] (tłum.) Paweł Izdebski. Warszawa: Wydawnictwo Naukowe PWN.

Brown, Roger W., Albert Gilman (1972) „The Pronouns of Power and Solidarity”. [W:]

Style and Language (red.), Thomas A. Sebeok. Boston: MIT Press. [Przedruk w:]

Language and Social Context, Pier Paolo Giglioli (red.) Middlesex, Baltimore, Ringwood: Penguin Books; 252-281.

Eelen, Gino (2001) A Critique of Politeness Theories. Manchester: St. Jerome Publishing. Garfinkel, Harold ([1967] 2007) Studia z etnometodologii [Studies in Ethnometodology] (tłum. A. Szulżycka). Warszawa: Wydawnictwo Naukowe PWN.

Huszcza, Romuald, 1996. Honoryfikatywność. Warszawa: Wydawnictwo Akademickie Dialog.

Hymes, Dell (1974) Foundations In Sociolinguistics. An Ethnographic Approach.

Philadelphia: University of Pennsylvania Press.

Geis, Michael, E (1995) Speech Acts and Conversational Interaction. Cambridge: Cambridge University Press. 
Goffman, Erving ([1959] 2000) Człowiek w teatrze życia codziennego [The Presentation of Self in Everyday Life]. (tłum. Helena Detner-Śpiewak i Paweł Śpiewak)Warszawa: Wydawnictwo

KR.

Goffman, Erving ([1967] 2006) Rytuat interakcyjny [Interaction Ritual] (thum. Alina Szulżycka) Warszawa: Wydawnictwo Naukowe PWN.

Goldnikowa, Alina (1973) Obycie ułatwia życie. Warszawa: Nasza Księgarnia. Jabłoński, Arkadiusz (2007) „Rama opisowa honoryfikatywności a komunikacja międzykulturowa". [W:] Komunikacja międzykulturowa: perspektywy badań interdyscyplinarnych. (Red.) Władysław Chłopicki Kraków: „Tertium”; 133-140.

Jabłoński, Arkadiusz (2007a) „Honorific Modification in a Layered Model of Communication". Lingua Posnaniensis XLIX; 51-67.

Jabłoński, Arkadiusz (2012) Honoryfikatywność japońska. Semiotyka a pragmatyka. Kraków: Wydawnictwo Uniwersytetu Jagiellońskiego.

Jabłoński, Arkadiusz (2013) Homeostaza tekstu. Tłumaczenie i komunikacja międzykulturowa w perspektywie polsko-japońskiej. Poznań: Wydawnictwo Naukowe UAM.

Jabłoński, Arkadiusz (2013a) "Współczesna honoryfikatywność polska. O bezpowrotnie traconej neutralności.” [W:] Stowo w kontekście. Aleksandra Knapik, Władysław Chłopicki, Piotr Chruszczewski (red.) Kraków: „Tertium”; 109-118.

Jabłoński, Arkadiusz (2015) „Jeszcze o neutralności. Ślepe zaułki pewnych gier honoryfikatywnych.” Homo Ludens 1(7); 111-124.

Jędrzejko, Ewa, Małgorzata Kita (2002) Słowa grzeczne i serdeczne. Warszawa: Ex Libris. Kamyczek, Jan (1974) Grzeczność na co dzień. Warszawa: Iskry.

Levinson, Stephen C. (1983) Pragmatics. Cambridge: Cambridge University Press. Marcjanik, Małgorzata (1997) Polska grzeczność językowa. Kielce: WSP.

Marcjanik, Małgorzata (2007) Grzeczność w komunikacji językowej. Warszawa:

Wydawnictwo Naukowe PWN.

Marcjanik, Małgorzata (2009) Mówimy uprzejmie. Warszawa: PWN.

Marcjanik, Małgorzata (2014) Słownik grzecznościowego savor-vivre’u. Warszawa: WUW. Marianowicz, Jan (1962) Grzeczność ułatwia życie. Warszawa: Ludowa Spółdzielnia Wydawnicza. 
Ożóg, Kazimierz (2005) „Model polskiej grzeczności językowej.” [W:] Język a kultura 17. (red.) Anna Dąbrowska, Alicja Nowakowska. Wrocław: Wydawnictwo Uniwersytetu Wrocławskiego; 9-16.

Pietkiewicz, Edward (1987) Dobre obyczaje. Warszawa: Instytut Wydawniczy Związków Zawodowych.

Płóciennik, Iwona, Daniela Podlawska (2007) Słownik wiedzy o języku. Bielsko-Biała: ParkEdukacja.

Yngve, Victor H. (1975) “Human Linguistics and Face-to-Face Interaction”. [W:]

Organization of Behavior in Face-to-Face Interaction. Adam Kendon, Richard M. Harris, Mary Ritchie Key (red.) The Hague, Paris: Mouton Publishers.

Zgółkowie, Halina i Tadeusz (2004) Językowy savoir-vivre. Praktyczny poradnik postugiwania się polszczyzna $w$ sytuacjach oficjalnych i towarzyskich. Warszawa: Książka i Wiedza.

\section{Źródła internetowe i inne źródla przykładów}

PoznańNM (2016). www.facebook.com/PoznanNM/ [data ostatniego dostępu: 2016.02.27].

Popularnie (2016). www.facebook.com/popularnie [data ostatniego dostępu 2016.02.29].

Allegro (2016). allegro.pl [data ostatniego dostępu 2014.10.29].

Windows Phone (2014). Komunikaty systemu Windows Phone 8.1, Lumia 920, wersja Lumia Cyan. 